\title{
SISTEM TEKNOLOGI INFORMASI DALAM RINTISAN DESA TANGGUH BENCANA
}

\author{
Muhamad Muhamad \\ Sekolah Pascasarjana UGM Universitas Gadjah Mada Yogyakarta \\ Direktorat Pengabdian Kepada Masyarakat Universitas Gadjah Mada Yogykarta \\ drmuhammad@ugm.ac.id
}

\begin{abstract}
Abstrak
Desa Tangguh Bencana merupakan suatu program pembentukan masyarakat desa agar lebih mandiri dalam menghadapi bencana yang melanda desa tersebut. Program ini dilakukan pada desa yang dianggap rentan terhadap bencana. Metode yang akan diterapkan dalam kegiatan Pengembangan masyarakat ini berupa kegiatan Sistem Informasi Desa yang berbasis teknologi informasi dengan partisipasi masyarakat dalam pemecahan setiap masalah melalui diskusi bersama. Selain itu juga akan dilakukan penanganan bencana bersifat struktural diantaranya pelengkapan alat kebencanaan dan jalur evakuasi. Hasil dari kajian bahwa pelaksanaaan program pengembangan masyarakat melalui sistem informasi ini juga akan didukung oleh mitra dari lembaga-lembaga yang berkaitan dengan masingmasing permasalahan. Selain itu menghasilkan rekomendasi a) masyarakat memiliki kesiapan dalam menghadapi ancaman bencana alam baik dari segi sarana dan infrastruktur maupun dari segi sumber daya manusia; b) upaya pemberdayaan selama tidak terjadi bencana akan mampu meningkatan indeks pembangunan manusia (IPM) berdasarkan aspek ekonomi, kesehatan, dan pendidikan; c) masyarakat mampu melakukan tindakan mitigasi dan pemulihan secara mandiri tanpa harus bergantung pada bantuan pemerintah ketika terjadi. Kesimpulan kelompok sasaran mampu mengaplikasikan Teknologi Tepat Guna Sistem Informasi (Community Based Information Network) Desa Tangguh Bencana. Hasil menunjukan bahwa partisipasi masyarakat sangat tinggi dan mampu mengoperasionalkan SID.
\end{abstract}

Kata-kata kunci: sistem informasi, tepat guna, tangguh bencana

\section{PENDAHULUAN}

Pendidikan tinggi merupakan pusat informasi dan pembelajaran baik bagi mahasiswa maupun masyarakat pada umumnya dan memegang peranan penting dalam penyelesaian berbagai permasalahan yang timbul di masyarakat seperti bencana alam, perubahan iklim, perubahan pola penularan penyakit, kekeringan berkepanjangan, banjir yang meluas, dan masalah lainnya yang terjadi sebagai salah satu akibat ulah manusia yang menyimpang dari sistem alam yang berkesinambungan, Haeruman,
H.J.S., Eriyatno, (2002). Usaha-usaha untuk mengubah pola pikir dan perilaku manusia agar menghentikan perilaku yang merusak serta memulai mengembangkan kesadaran, kemampuan dan kemauan untuk memperbaiki kondisi unsustainable' menjadi sustainable' perlu dilakukan.

Keberlangsungan wilayah perdesaan harus mendapat dukungan sepenuhnya didalam pengimplentasian program Pemberdayaan Pembelajaran Masyarakat (PkM) terutama tentang Pemanfaatan penelitian dan pemanfaatan Teknologi Tepat Guna yang merupakan program

Teknologi Informasi dan Komunikasi 
keberlangsungan dan terintegrasi dengan program KKN PPM UGM antar semester 2017. Program terkonsentrasi kepada rintisan desa tangguh bencana.

Desa Tangguh Bencana merupakan suatu program pembentukan masyarakat desa agar lebih mandiri dalam menghadapi bencana yang melanda desa tersebut, Setyawan. B., Rahmi, D.H., Mitchell, B. (2000),. Program ini dilakukan pada desa yang dianggap rentan terhadap bencana. Adapun desa yang dimaksud dalam adalah Desa Kalibening, Kecamatan Dukun, Kabupaten Magelang. Desa Kalibening adalah Desa terdekat kedua setelah Desa Argomulyo, dan dianggap rentan terhadap bencana karena jaraknya hanya sekitar $6,8 \mathrm{~km}$ dari puncak Merapi. Keadaan ini tentunya sangat membahayakan keberlangsungan hidup warga di desa Kalibening yang mayoritas berprofesi sebagai petani. Pada erupsi Gunung Merapi pada tahun 2010 lalu menimbulkan banyak kerugian baik berupa harta benda bahkan jiwa.

Karena Gunung Merapi memiliki siklus letusan 3-4 tahun, maka program ini sangat cocok untuk Desa Kalibening agar masyarakat desa tersebut lebih mandiri dalam menghadapi bencana yang melanda tanpa harus menunggu pertolongan dari pihak luar. Program desa tangguh bencana dalam PPM ini merupakan program lanjutan dari kegiatan KKN-PPM tahun lalu sehingga tahapan pembentukan desa tangguh bencana pada tahun ini pun tetap sama, yaitu: (1) Pengumpulan Data, (2) Penyusunan sistem informasi untuk program desa tangguh bencana, dan (3) Pengaplikasian program.

Program ini telah mendapat dukungan penuh dari Direktorat Pengabdian Kepada Masyarakat Universitas Gadjah Mada (DPKMUGM) melalui hasil Penelitian dan Penerapan Teknologi Tepat Guna (TTG) yang kegiatannya melalui Pembelajaran Pemberdayaan Masyarakat (KKN-PPM). Selain itu, program ini juga diselenggarakan atas izin dari pemerintah Kabupaten Magelang dan perangkat Desa Kalibening, Kecamatan Dukun sehingga pihak- pihak tersebut juga akan ikut memonitoring keberlangsungan program ini.

Beberapa pihak lain yang terlibat dalam rintisan desa tangguh bencana antara lain Badan Penanggulangan Bencana Daerah ditingkat provinsi maupun Kabupaten. Hal ini merupakan upaya-upaya yang terkoordinasi antara institusi pemerintah pusat dengan daerah. Beberapa pihak lain yang terlibat antara lain dengan NGO kebencanaan yang kehadirannya sangat membantu baik didalam pencegahan maupun pengendaliannya.

Melalui kegiatan PPM Pemanfataan Teknologi Tepat Guna berjudul "Rintisan Masyarakat Tangguh Bencana" ini, diharapkan Desa Kalibening dapat menjadi desa tangguh bencana yang siap dalam menghadapi bencana dan menjadi desa yang mandiri. Tujuan terpenting dari kegiatan Pengembangan masyarakat ini berupa kegiatan Sistem Informasi Desa (SID) yang berbasis teknologi informasi dan mengikut sertakan partisipasi masyarakat dalam pemecahan setiap masalah melalui diskusi bersama. Selain itu juga akan dilakukan penanganan bencana bersifat struktural diantaranya SID sebagai bagian pelengkapan alat informasi kebencanaan dan jalur evakuasi. Dalam pelaksanaaan program Pengembangan masyarakat melalui sistem informasi ini juga akan didukung oleh mitra dari lembaga-lembaga yang berkaitan dengan masing-masing permasalahan.

Melalui keberlanjutan potensi desa diharapkan dapat menjadi dasar pijakan yang akurat bagi pelaksanaan program-program pengembangan desa yang sesuai dengan kebutuhan wilayah pedesaan khususnya desa Kalibening di Kecamatan Dukun Kabupaten Magelang. Seiring dengan perkembangan teknologi, penyampaian informasi seringkali dilakukan melalui media-media digital, dari media sosial hingga penggunaan website. Hal ini dilakukan karena pemanfaatan internet sudah dilakukan oleh banyak orang dari berbagai kalangan. Ditambah pula, dengan pemanfaatan

Teknologi Informasi dan Komunikasi 
internet, informasi dapat disampaikan ke banyak orang dalam satu waktu sekaligus, sehingga dapat menyingkat waktu dan meminimalkan dana yang dibutuhkan apabila dibandingkan dengan penyampaian informasi yang dilakukan secara manual (misal dengan pamflet, surat kabar, dan lain-lain).

Hal tersebut yang melatarbelakangi pembuatan Sistem Informasi desa (SID) untuk Desa Kalibening, mengingat Desa Kalibening merupakan daerah rawan bencana Gunung Merapi dan masuk dalam wilayah KRB III. Dengan keadaan tersebut, SID semakin diperlukan untuk menyampaikan informasi yang terkait dengan bencana baik dari pencegahan, penanganan, dan pemulihan dari bencana Gunung Merapi yang bisa terjadi kapan pun. Dalam hal ini, sasaran utama pengguna website merupakan warga Desa Kalibening ataupun sekitarnya yang juga merupakan daerah rawan bencana Gunung Merapi. Sehingga informasi dapat secara mudah diakses oleh seluruh warga setempat dari mana pun dan kapan pun.

Penyampaian informasi-informasi penting melalui Sistem Informasi Perdesaan dapat digunakan untuk memperkenalkan Desa Kalibening ke orang lain karena terdapat begitu banyak potensi dan hal unik yang terdapat di Desa Kalibening. Sasaran pengguna website merupakan orang yang berasal dari luar Desa Kalibening. Sehingga mereka dapat mengenal Desa Kalibening dan mengetahui berbagai macam potensi dan keunikan yang ada. Hal yang terpenting adalah bagaimanakah masyarakat memperkenalkan pemanfaatan Teknologi Tepat Guna ini. Sehingga masyarakat lebih aktif sebagai administrator pengunggah dan pengunduhannya secara berkelanjutan.

\section{METODE}

Metoda pelaksanaan dalam kegiatan PkM ini berupa RRA yang merupakan proses belajar yang intensif untuk memahami kondisi perdesaan, dilakukan berulang-ulang, dan cepat. Untuk itu diperlukan cara kerja yang khas, seperti tim kerja kecil yang bersifat multidisiplin, menggunakan sejumlah metode, cara, dan pemilihan teknik yang khusus, untuk meningkatkan pengertian atau pemahaman terhadap kondisi perdesaan, Haeruman, H.J.S., Eriyatno, (2002) Cara kerja tersebut tersebut dipusatkan pada pemahaman pada tingkat komunitas lokal yang digabungkan dengan pengetahuan ilmiah. Komunikasi dan kerjasama diantara masyarakat desa dan aparat perencana dan pelaksana pembangunan (development agent) adalah sangat penting, dalam kerangka untuk memahami masalah-masalah di perdesaan. Metoda RRA juga berguna dalam memonitor kecenderungan perubahan-perubahan di perdesaan untuk mengurangi ketidakpastian yang terjadi di lapangan dan mengusulkan penyelesaian masalah yang memungkinkan.

Menurut Baiquni (2001), dan Muhamad (2014) metoda RRA menyajikan pengamatan yang dipercepat yang dilakukan oleh dua atau lebih pengamat atau peneliti, biasanya dengan latar belakang akademis yang berbeda. Metoda ini bertujuan untuk menghasilkan pengamatan kualitatif bagi keperluan pembuat keputusan untuk menentukan perlu tidaknya penelitian tambahan dalam merencanakan dan melaksanakan kegiatan. Metoda RRA memiliki tiga konsep dasar yaitu; (a) perspektif sistem, (b) triangulasi dari pengumpulan data, dan (c) pengumpulan data dan analisis secara berulangulang (iterative).

Penerapan Teknologi Tepat Guna yaitu tentang sistem informasi perdesaan (SID). Seperti telah diketahui, pada Rancangan UndangUndang Desa yang kini sedang dikebut penyelesaiannya, ada sebuah pasal yang mengatur kewajiban untuk mengembangkan sistem informasi desa (SID). Pada pasal 73 RUU Desa itu, sistem informasi desa disusun berdasarkan data monografi desa yang dikelola oleh pemerintah desa dan harus dapat diakses oleh pemangku kepentingan. 


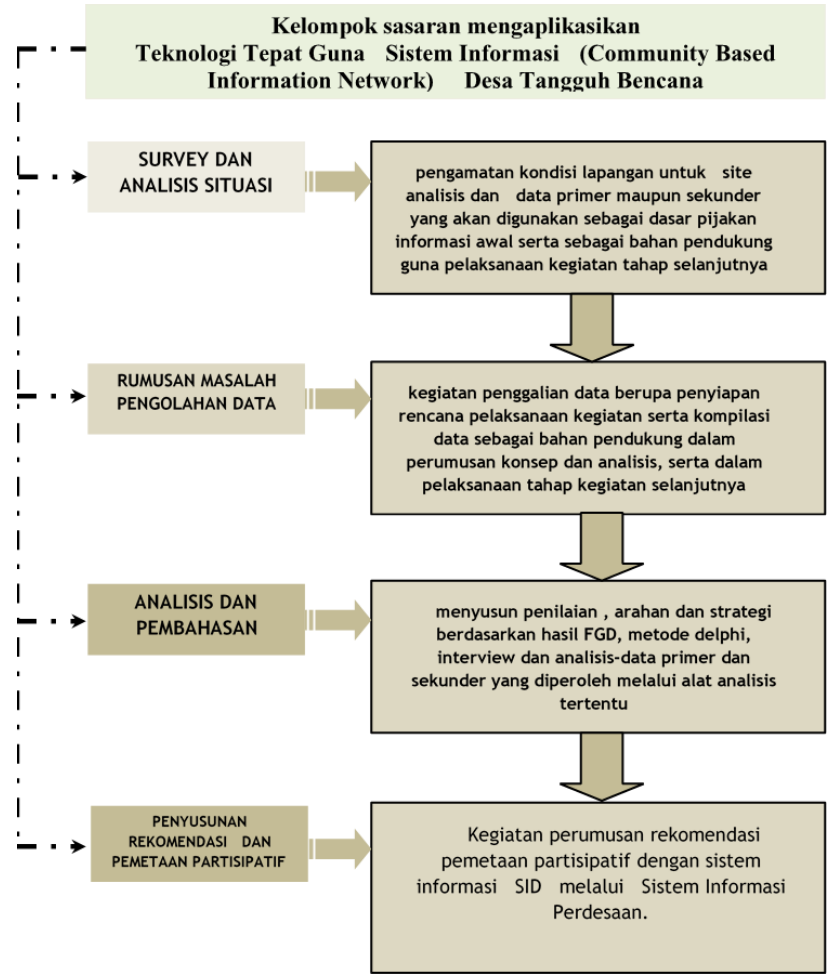

Diagram Lingkup Kegiatan Pokok. Sumber: Analisis, 2020
Lingkup kegiatan yang ada dalam pekerjaan ini dengan Community Based Information Network sesuai dengan rencana seperti pada skema diatas, yaitu:

1) Melakukan survey dan proses pencarian data, Menetapkan alat atau metoda atau teori pengolahan data, Melakukan berbagai analisa Menetapkan rekomendasi-

2) Meningkatkan kapasitas pengelolaan bencana dengan memperkuat multi metode pelatihan, Memperkuat kekayaan etno-tipemetodologi kebencanaan, Memperkuat penggunaan multi-modul (SMS, Web, database, offline, Mengembangkan infrastruktur informasi dan komunikasi di situasi darurat, Membangun jejaring dengan berbagai pemangku kepentingan yang terkait dengan penanggulangan bencana seperti BNPB, kalangan pemerintah dari tingkat kecamatan hingga provinsi, dan lain-lain

3) Membangun SID sebagai upaya kelola database desa untuk mendukung Analisa Risiko dan kebijakan Pemdes dalam menyusun RAD Pendampingan pemanfaatan SID pada masa darurat

\section{Metode Pengumpulan Data.}

Berdasarkan lingkup kegiatan yang akan dilaksanakan dalam pekerjaan ini, yang mencakup 4 (lima) pokok kegiatan, yaitu: (1) persiapan (studi literatur,pengumpulan data sekunder), ( 2) observasi/survei lapangan, (3) analisis dan pembahasan (4) penyusunan laporan, untuk setiap tahap pelaporan; maka beberapa metode pelaksanaan akan digunakan untuk mencapai tujuan dan sasaran yang diharapkan. Jabaran metode untuk masingmasing kegiatan dapat diuraikan sebagai berikut:

\section{Persiapan dan Kajian Pustaka}

Kegiatan penyiapan rencana pelaksanaan kegiatan serta kompilasi data dan informasi awal sebagai bahan pendukung dalam perumusan konsep dan analisis serta dalam pelaksanaan tahap kegiatan selanjutnya (survei dan kompilasi data lapangan bersama kelompok sasaran mengaplikasikan ilmu pengetahuan tentang bagaimana membuat peta partisipatif kognitif untuk melakukan identifikasi potensi-potensi kepariwisataan alam agar dapat dikemas melalui produk wisata yang mempunyai nilai jual.

Metode yang dipakai didalam melakukan persiapan dan kajian pustaka yaitu mencari dan menemukan kelompok sasaran masyarakat di wilayah studi. Sedangkan studi Pustaka, yaitu mendalami berbagai literatur yang berkaitan dengan topik studi. Teknik yang digunakan

Teknologi Informasi dan Komunikasi 
adalah melalui pendalaman berbagai sumber informasi . seperti buku, artikel, majalah, internet, dsb; serta mencermati model-model yang telah berjalan.

\section{Survey dan Kompilasi Data}

Kegiatan penyiapan rencana pelaksanaan kegiatan serta kompilasi data dan informasi awal sebagai bahan pendukung dalam perumusan konsep dan analisis serta dalam pelaksanaan tahap kegiatan selanjutnya (survei dan kompilasi data lapangan. Sedangkan studi studi pustaka diperlukan untuk mendalami berbagai literatur yang berkaitan dengan topik studi. Teknik yang digunakan adalah melalui pendalaman berbagai sumber informasi seperti buku, artikel, majalah, internet, dsb; serta mencermati model-model yang telah berjalan. Penelitian ini menggunakan metode metode kualitatif.

Metode kualitatif dalam studi ini akan diterapkan melalui indepth interview maupun observasi lapangan di Desa Kalibening. Secara konkret metode pengumpulan data tersebut dijabarkan sebagai berikut: a) Survey dilakukan secara langsung ke lapangan untuk melihat kondisi aktual yang akan dikembangkan dan potensi masyarakat yang ada sebagai dasar penetapan pemetaan partisipatif yang sesuai. Penilaiannya akan dilakukan dengan menggunakan daftar periksa (check list) dimasing-masing kegiatan, b) Indepth interview akan dilakukan dalam bentuk wawancara secara mendalam dengan tokoh-tokoh atau pelaku kunci yang terkait dengan isu/ permasalahan kelompok masyarakat.. Sasaran indepth interview tersebut mencakup antara lain: aparat di lingkungan pemerintahan desa pemuda dan pemudi, komunitas Radio Merapi dan industri agro atau unsur terkait lainnya. Kegiatan ini akan dilakukan di wilayah penelitian yaitu Desa Kalibening, Kecamatan Dukun, Kabupaten Magelang.

\section{Tahapan Analisis}

Tahapan analisis yang dipergunakan didalam PPM ini adalah pendekatan dan metode partisipatif didalam. Selanjutnya metode yang secara umum adalah mencari skala prioritas, yaitu mengurutan permasalahan-permasalahan dan masalah terberat yang dianggap krusial akan diprioritaskan dan di justifikasi di tingkat pertama (Azwar, 1995) dan (Baiquni , 2001), Lodewijk M.N, (2013). Beberapa langkah dan metode yang dipergunakan antara lain: Pemetaan partisipatif; yaitu upaya kegiatan pelatihan perumusan masalah yang bertujuan untuk mengenali permasalahan secara detail dikawasan sebagai bagian langkah-langkah kecil dan sederhana dari sejumlah langkah besar yang harus ditempuh oleh masyarakat sendiri (Azwar, S., 1995)

Metode tersebut dapat diimplementasikan berupa Pembuatan website Desa Kalibening dilakukan selama KKN-PPM tahun 2017 berlangsung. Website dibangun tidak memanfaatkan penyedia layanan blog seperti blogspot.com atau wordpress.com dengan tujuan agar dapat dilakukan pengembangan terhadap website tersebut sesuai dengan yang diinginkan, baik dari segi tampilan ataupun fitur-fiturnya. Selain itu, dengan cara tersebut data-data yang ada dapat disimpan dalam suatu database yang dibuat dan dapat diakses apabila dibutuhkan. Adapun tampilan atau layout website memanfaatkan dari template yang sudah ada, sehingga hanya perlu dilakukan modifikasi untuk menyesuaikan dengan tampilan yang diinginkan, misalnya untuk bagian logo, header, fitur, dan lain-lain. Website Desa Kalibening dapat diakses melalui www.desakalibening.com. 


\section{HASIL DAN PEMBAHASAN}

Sitem Informasi Desa berupa Website Desa Kalibening dapat diakses melalui www.desakalibening.com. Domain dan hosting www.desakalibening.com diperoleh dari idhostinger yang merupakan salah satu penyedia layanan tersebut.. Upload atau publish website yang dibuat, dilakukan melalui akun idhostinger yang dimiliki menggunakan username dan password yang ada. Menu-menu yang terdapat dalam website adalah sebagai berikut:

\section{a. Beranda (Halaman Depan}

Beranda merupakan halaman awal website, sehingga apabila pengguna mengakses www.desakalibening.com, maka pengguna akan secara otomatis diarahkan ke halaman beranda, yaitu www.desakalibening.com/home. Di halaman ini, ditampilkan informasi secara umum website, seperti artikel terbaru, foto terbaru, indeks website, dan beberapa fitur tambahan seperti, kolom pencarian konten, statistik pengunjung dan kalender. Berikut merupakan tampilan beranda website Desa Kalibening dibawah ini:
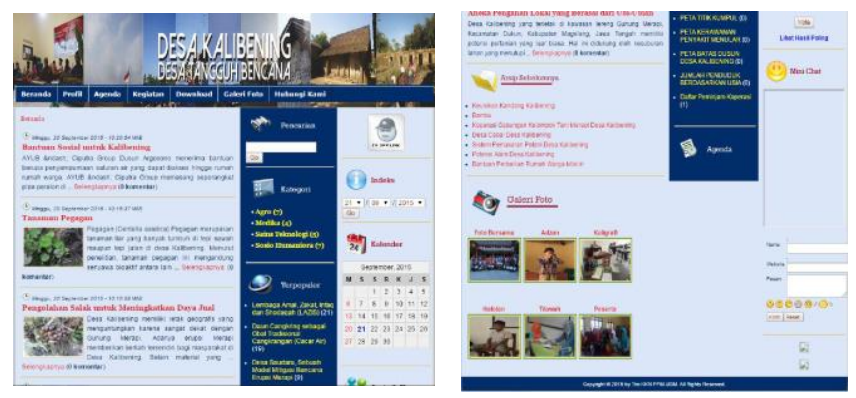

Gambar 1. Beranda halaman depan. Sumber: Analisis TTG, 2020

\section{b. Profil Desa Kalibening}

Profil merupakan halaman statis yang berisi uraian tentang profil Desa Kalibening yang menggambarkan Desa Kalibening secara umum. Berikut merupakan tampilannya:

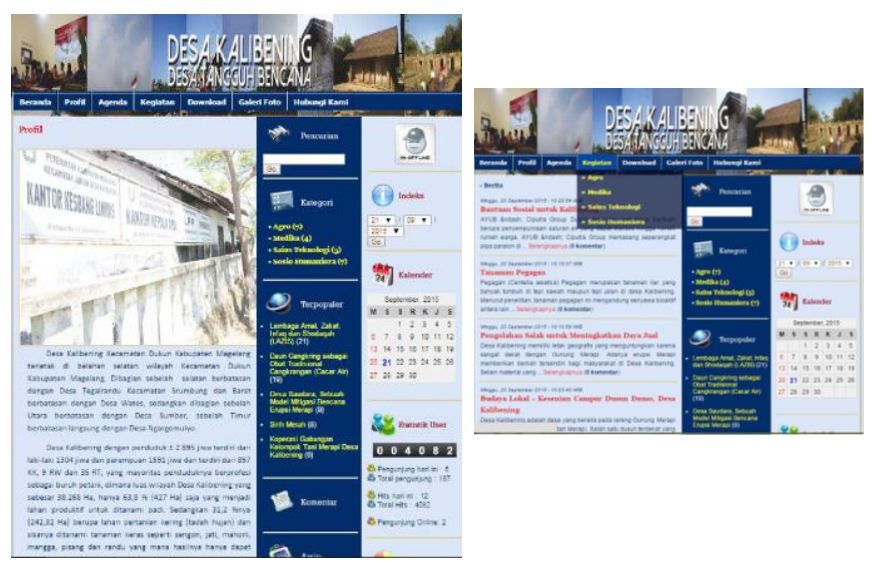

Gambar 3. Profil halaman depan dan Kategori Kegiatan. Sumber: Analisis TTG, 2020

Kegiatan dibedakan menjadi 4 kategori, yaitu Agro, Medika, Sains Teknologi, dan Sosio Humaniora. Sehingga, suatu artikel tentang kegiatan tertentu akan dikategorikan ke dalam salah satu dari keempat kategori tersebut. Berikut merupakan tampilan halaman kegiatan yang diurutkan berdasar artikel mana yang paling baru: Halaman ini berisi file-file yang dapat didownload oleh pengguna. Misalkan, peta jalur evakuasi, APBDes, dan lain-lain. Berikut tampilan halaman download:

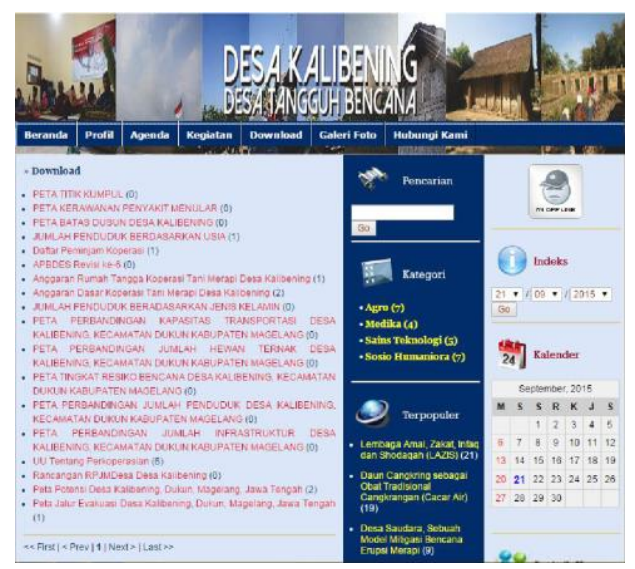

Gambar 5. Tampilan Download. Sumber: Analisis TTG, 2020 
Keunggulan dari penerpan sistem informasi desa (SID) antara lain bagi masyarakat Desa Kalibening:

a. Masyarakat memiliki mengetahui potensi desa yang ditinggali baik dari segi sarana dan infrastruktur maupun dari segi sumber daya manusia.

b. Upaya pemberdayaan selama tidak terjadi bencana akan mampu meningkatan indeks pembangunan manusia (IPM) berdasarkan aspek ekonomi, kesehatan, dan pendidikan.

c. Desa Kalibening menjadi desa percontohan desa tangguh bencana dan menjadi pusat riset kebencanaan bagi desa-desa di sekitar gunung api Merapi.

d. Harapan dari program kedepan Pemanfaatan Teknologi Tepat Guna (TTG) melalui sistem informasi perdesaan (SID) adalah dapat memperoleh informasi percontohan desa tangguh bencana sehingga dapat menerapkannya pada masing-masing desa yang memiliki kerawanan tinggi terhadap bencana erupsi gunung api.

Beberapa tingkat kesulitan pelaksanaan antara lain:

a) Akses internet yang susah di lokasi yang mengakibatkan beberapa proses pembuatan website dilakukan berulang kali karena gagal. Misalnya, saat pengisian data website yang diulang hingga 3 kali karena internet yang tidak stabil. Sedangkan untuk pengulangannya tersebut dapat dilakukan di hari berikutmya. Selain itu, saat mempublish website juga harus dilakukan berulang kali sampai akhirnya semua file dapat terunggah. Namun, kesulitan ini dapat diatasi meskipun membutuhkan waktu.

b) Pelaksana kurang ahli dalam hal pembuatan website dan sangat sedikit mahasiswa yang mengerti tentang pembuatan website. Hal ini mengakibatkan website dibuat dalam kurun waktu yang lama dengan tampilan yang masih sangat sederhana. Namun begitu, banyak dukungan dan bantuan yang telah diberikan Desa Kalibening. Mereka mencari bahan yang dapat dijadikan konten website dan setelah itu pengunggahan konten dilakukan oleh beberapa warga masyarakat, sehingga proses upload dapat berlangsung lebih cepat. Dengan bantuan tersebut, website www.desakalibening.com dapat diakses.

\section{KESIMPULAN}

1) Ketercapaian Program penerapan teknologi tepat guna berupa sistem informasi- desa (SID) sangat penting yang digunakan untuk memperkenalkan Desa Kalibening . karena terdapat begitu banyak potensi dan hal unik yang terdapat di Desa Kalibening, sasaran pengguna merupakan orang yang berasal dari luar Desa Kalibening.

2) Ketepatan sasaran dan kesesuaian antara persoalan yang dibutuhkan didasarkan besarnya potensi bencana yang dapat terjadi khususnya di Desa Kalibening, maka sangat diperlukan rencana strategis dan komprehensif untuk penanggulangan bencana.

3) Metode yang menekankan kelompok sasaran mengaplikasikan Teknologi Tepat Guna Sistem Informasi (Community Based Information Network) Desa Tangguh Bencana merupakan hal terpenting suksesnya pelaksanaan. Penyelenggaraan penanggulangan bencana bertujuan untuk menjamin terselenggaranya pelaksanaan penanggulangan bencana secara terencana, terpadu, terkoordinasi, dan menyeluruh dalam rangka memberikan perlindungan kepada masyarakat dari ancaman, risiko, dampak bencana.

4) Dampak yang diperoleh antara lain masyarakat mempunyai modal sosial yang tinggi untuk menumbuhkan semangat hidup yang harmonis dengan alam. Rekomendasi untuk kegiatan Pkm berukutnya dapat dilakukan melalui (1) mempelajari informasi

Teknologi Informasi dan Komunikasi 50 
spasial kawasan rawan bencana, (2) beradaptasi hidup di kawasan rawan bencana, (3) bila tidak layak huni sebaiknya pindah di tempat yang layak, (4) tanggap bila terjadi bencana, (5) tata ruang dan guna lahan yang berbasis bencana, (6) penguatan sistem manajemen bencana.

\section{REFERENSI}

1. Azwar, S., 1995, Sikap Manusia Teori dan Pengukurannya, Yogyakata, Liberty.

2. Birkeland, C., 1983, Influences of Topography of Nearby Land Masses in Combination with Local water Movement Patterns on the nature of Nearshore Marine Communities, Productivity and Processes in Island Marine Ecosystem. UNESCO Report in Marine Science No. 27 Dunedine, page: $16-31$

3. Baiquni, M, (2001), Participatory Rural Appraisal, Pendekatan dan Metode Partisipatif Dalam Pembangunan Masyarakat, National Training Session Cohort IX, Makalah disampaikan pada LEAD Leadership Environmental and Development, YPB Yayasan Pembangunan Berkelanjutan, Jakarta. 4. ( 1991), Buku

Panduan Air dan Sanitasi, Pusat Informasi Wanita dalam Pembangunan, PDII-LIPI bekerjasama dengan Swiss Development Cooperation, Jakarta,

5. Haeruman, H.J.S., Eriyatno, 2002, Kemitraan dalam Pengembangan Ekonomi Lokal, Penerbit Yayasan Mitra Pembangunan Desa-Kota dan Busines Inovation Centre Indonesia, Jakarta.
6. Muhamad, Fandeli Khafid (2009), Prinsip-prinsip Dasar Mengkonservasi Lanskap, Gadjah Mada University Press, Yogyakarata.

7. Muhamad. (2010), Kepariwisataan Berkelanjutan di Wilayah Yogyakarta Utara Setelah Erupsi 2010, (Interaksi Masyarakat di dalam Pengelolaan Lingkungan dan Kepariwisataan Alam), Disertasi Sekolah Pascasarjana Universitas Gadjah Mada Yogyakarta, Tidak diTerbitkan dan Tidak di Publikasikan, Yogyakarta.

8. Muhamad. (2014), Lanskap Kepariwisataan Alam, Gadjah Mada University Press, Yogyakarata

9.

$$
\text { Penulisan Proposal, Pengembangan }
$$

Program Pengabdiaqn Kepada

Masyarakat Berbasis Pemanfaatan Hasil

Penelitian dan Penerapan Teknologi

Tepat Guna, Lembaga Penelitian dan Pengabdian Kepada Masyarakat Universitas Gadjah Mada Yogyakarta.

10. Maha Neni Lodewijk, (2013)

Participatory Rural Appraisal, Pendekatan dan Metode Partisipatif Dalam Pembangunan Masyarakat, Bandung

11. Setyawan. B., Rahmi, D.H., Mitchell, B., (2000), Pengelolaan Sumberdaya dan Lingkungan Hidup, Gadjah Mada University Press, Yogyakarta. 